\title{
Role of Octreotide in Menetrier's Disease: Case Report and Review of Literature
}

\author{
Aadil Khan ${ }^{1}$, Anuj Chhaparia ${ }^{2}$, Muhammad B. Hammami ${ }^{3,1}$, Christine Hachem ${ }^{1}$ \\ 1. Internal Medicine: Gastroenterology, Saint Louis University School of Medicine, St. Louis, USA 2. Internal Medicine, \\ Saint Louis University School of Medicine, St. Louis, USA 3. Internal Medicine: Gastroenterology, University of \\ California Riverside, Riverside, USA
}

Corresponding author: Aadil Khan, aadil.khan@health.slu.edu

\begin{abstract}
Menetrier's disease (MD) is a rare disease characterized macroscopically by gastric rugae thickening and microscopically by foveolar hyperplasia with glandular atrophy, resulting in luminal protein loss. Different treatment strategies, including antibiotics, prednisone, octreotide, and monoclonal antibodies, have yielded varying degrees of success. Here, we present a rare complication of MD with a gastric outlet obstruction from a large adenoma. However, prior to this complication, dramatic clinical and laboratory improvements were observed after 12 months of treatment with subcutaneous octreotide. We also present a review of the literature for the role of octreotide in the treatment of MD.
\end{abstract}

Categories: Gastroenterology

Keywords: menetrier's disease, octreotide, gastric adenoma, juvenile polyposis syndrome

\section{Introduction}

Menetrier's disease (MD) is a protein-losing enteropathy (PLE). The uniting factor of PLE conditions is the excessive sequestration of serum protein into the gut lumen. This leads to loss of serum protein [1]. MD presents as enlarged rugae due to hyperplastic mucous cells in the stomach wall. Because the rugae are enlarged, there is an abnormally high number of mucous cells, which release protein-containing mucous into the stomach. As a result, hypoproteinemia ensues, as hypersecretion of mucous into the gastrointestinal tract depletes plasma proteins. Patients with this disorder present with a plethora of symptoms and signs, including nausea, vomiting, abdominal pain, edema in peripheral tissues, anemia, hypoalbuminemia, and hypochlorhydria.

While the exact etiology of MD is unknown, there have been experiments implicating increased signaling of epidermal growth factor-receptor (EGF-R) through transforming growth factor a (TGF-a) [2]. MD has also been shown to be associated with cytomegalovirus and Helicobacter pylori as well as other infections, but there are also many cases in which these microorganisms have not been detected [3].

Received 09/01/2020

Review began 10/05/2020 Review ended 10/18/2020 Published 11/16/2020

\section{() Copyright 2020}

Khan et al. This is an open access article distributed under the terms of the Creative Commons Attribution License CC-BY 4.0., which permits unrestricted use, distribution, and reproduction in any medium, provided the original author and source are credited.
Treatment of MD through drugs has yielded inconsistent or mixed results. Several pharmacological agents, including prednisone, antibiotics, specific $H$. pylori treatment, and non-steroidal anti-inflammatory drugs have shown variable success and no universal therapy is established [4]. Cetuximab has more recently been cited as an effective therapy, but it is not a cure. [5] Gastrectomy remains the treatment of choice for cases refractory to medical treatment [6]. In this case, we present a patient with MD which was successfully managed using octreotide, a somatostatin analog.

\section{Case Presentation}

A 52-year-old African American man presented for evaluation of fatigue and anemia. He was noted to have a hemoglobin of $6 \mathrm{~g} / \mathrm{dL}$ with a mean corpuscular volume (MCV) of $58 \mu \mathrm{m} 3$. On initial imaging, he exhibited what appeared to be a large gastric mass or a thickened fold (Figure 1). An esophagogastroduodenoscopy (EGD) demonstrated large gastric folds with increased thickness (Figure 2). Gastric biopsies were performed and revealed dilated hyperplastic foveolar glands with stromal edema, characteristic of MD (Figure 3). In addition, lab values were consistent with ferritin of $8 \mathrm{ng} / \mathrm{ml}$, iron of $<5 \mathrm{mcg} / \mathrm{dL}$, and an albumin of $0.9 \mathrm{~g} / \mathrm{dL}$ (Table 1). A stool alpha-1-antitrypsin showed high clearance ( $>59 \mathrm{~mL} /$ day). The diagnosis of MD was made using the pathognomonic endoscopic and histologic findings in the setting of hypoalbuminemia, iron deficiency anemia and positive 24-hour alpha-1-antitrypsin clearance test. No microorganisms, including $H$. Pylori and CMV, were identified. 


\section{Cureus}

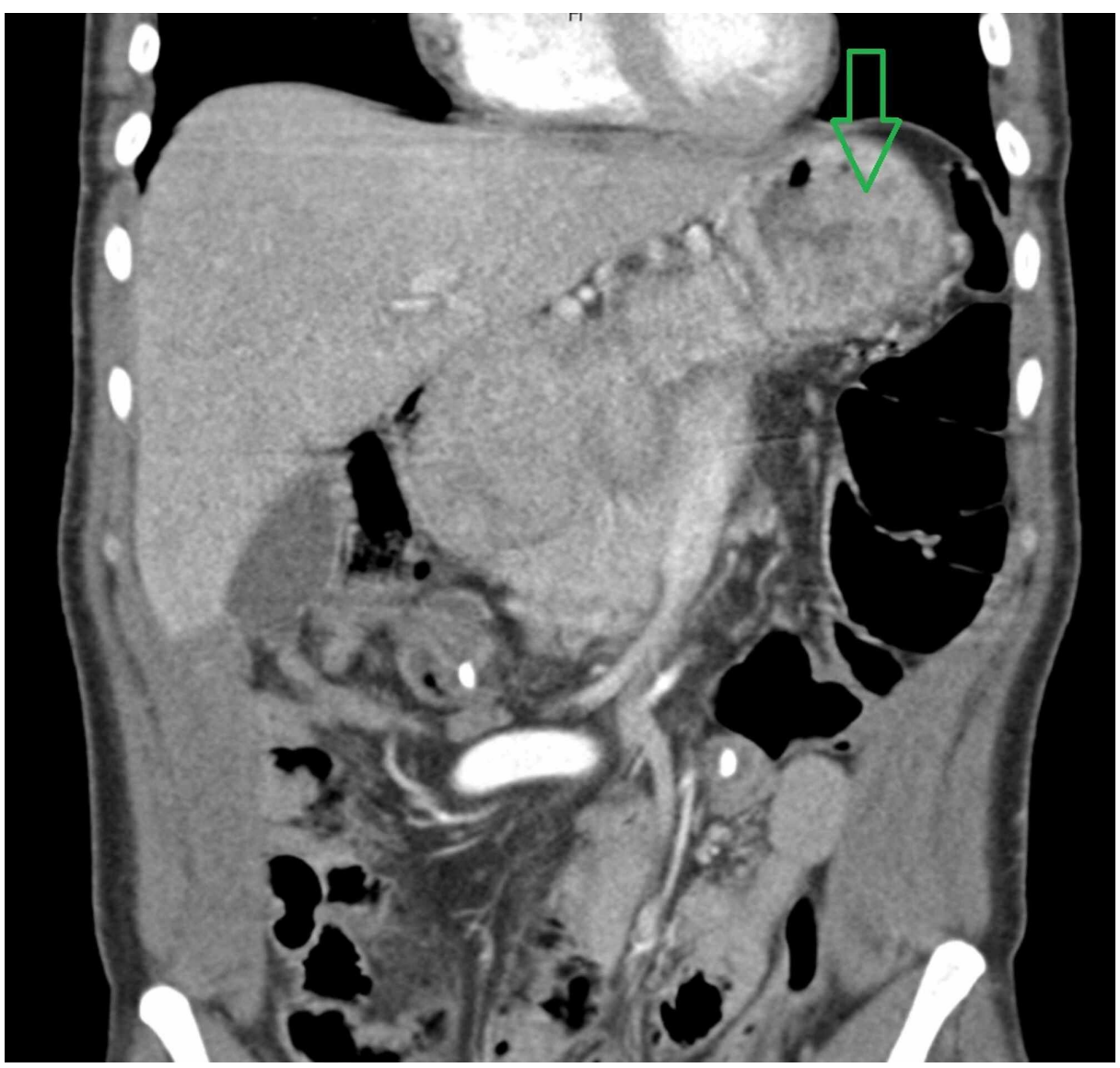

FIGURE 1: Coronal section showing mass-like thickening of the gastric wall.

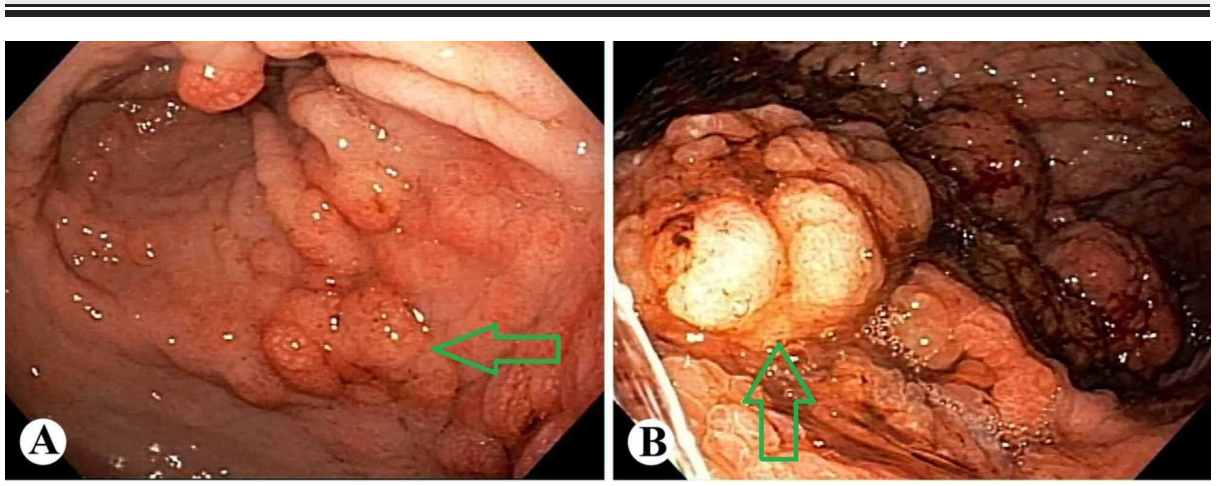

FIGURE 2: Endoscopic appearance of the stomach showing edematous mucosa and polypoid changes of the gastric fundus (A) and body (B). 


\section{Cureus}
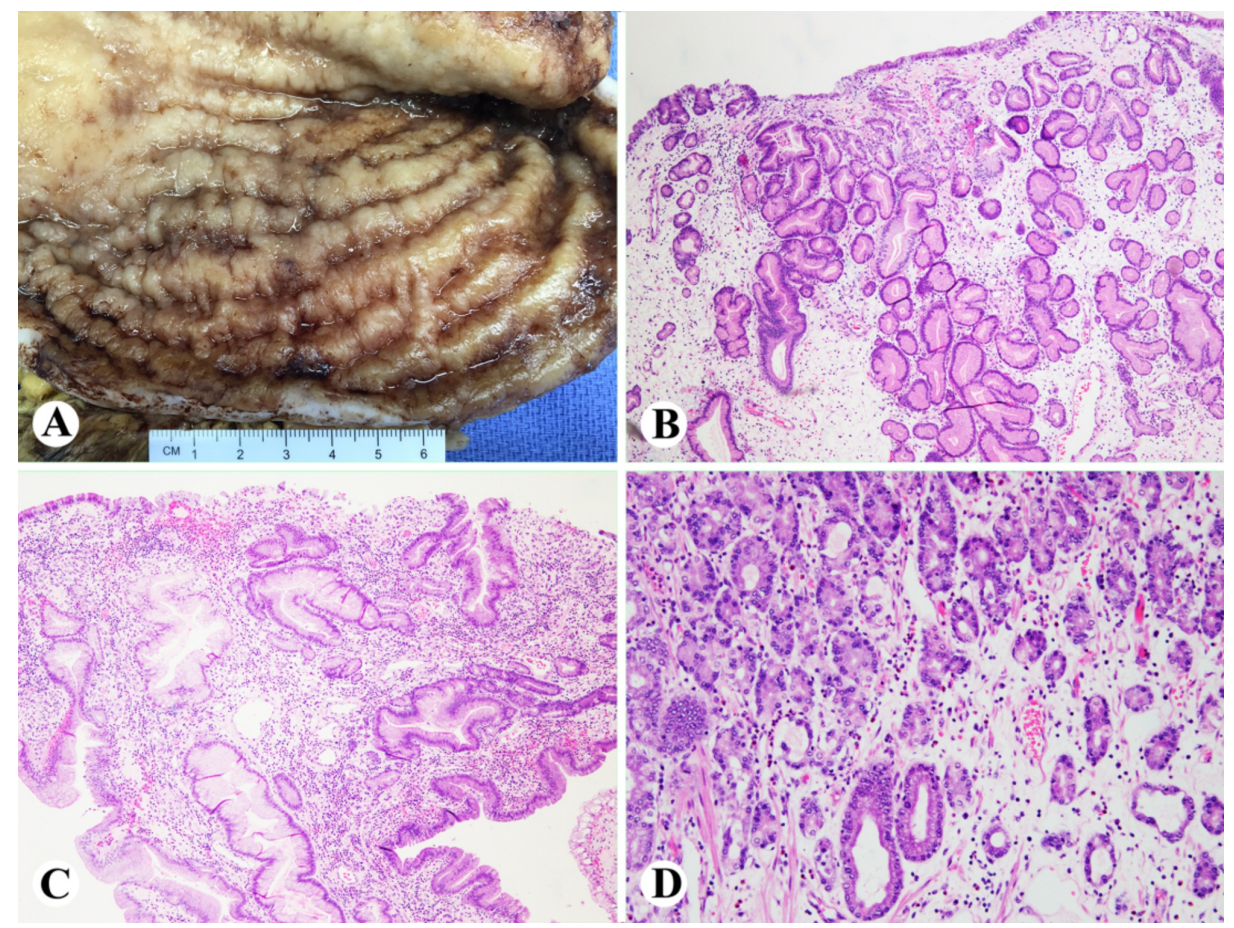

FIGURE 3: Grossly, hypertrophied gastric mucosa (A); histologically, gastric body and fundal mucosa with edematous, mildly inflamed lamina propria with hyperplastic, tortuous and dilated foveolar glands, and loss of parietal cells (B-D).

\begin{tabular}{|c|c|c|c|}
\hline & $\begin{array}{l}\text { Day } 1 \text { of octreotide } \\
\text { treatment }\end{array}$ & $\begin{array}{l}\text { Six months into octreotide } \\
\text { treatment }\end{array}$ & $\begin{array}{l}\text { One year into octreotide } \\
\text { treatment }\end{array}$ \\
\hline Albumin (g/dL) & 0.9 & 2.8 & 2.9 \\
\hline Hemoglobin (g/dL) & 6.0 & 14.4 & 14.4 \\
\hline Iron (mcg/dL) & $<5$ & 116 & 125 \\
\hline Body Weight (lbs) & 164 & 159 & 180 \\
\hline Ferritin (ng/mL) & 8 & 37 & 19 \\
\hline $\begin{array}{l}\text { Alpha-1-Antitrypsin } \\
\text { (mg/dL) }\end{array}$ & 220 & NR & 370 \\
\hline
\end{tabular}

TABLE 1: Effect of octreotide treatment on laboratory values in a patient with Menetrier's disease.

The patient was started on 100ug twice daily of subcutaneous octreotide for seven months and then transitioned to $20 \mathrm{mg}$ of octreotide long-acting release (LAR) for five months. The entire course of treatment was 12 months, and during that time, his albumin increased from $0.9 \mathrm{~g} / \mathrm{dL}$ to $2.9 \mathrm{~g} / \mathrm{dL}$; his anemia and iron deficiency returned to normal values (Table 1 ). He also regained significant muscle mass that he had previously lost before treatment (Table 1 ).

At the end of his 12-month treatment with octreotide, he developed a gastric outlet obstruction (Figure 4). He underwent an EGD which showed a large gastric polyp extending into the duodenum resulting in near complete obliteration of duodenal lumen (Figure 5). Pathology was consistent with gastric adenoma (Figure 6). The patient required total gastrectomy with Roux-en-Y gastrojejunostomy for gastric outlet obstruction. He recovered fully from the surgery and continued to do well up to three years of follow up. Around this time, the patient was also diagnosed with juvenile polyposis syndrome (JPS). He had a history of multiple colonic tubulovillous adenomas with dysplastic changes and genetic screening revealed a SMAD4 c153dupA mutation. He is enrolled in a cancer screening program and is receiving regular colonoscopies, EGDs, video 


\section{Cureus}

capsule endoscopies and endoscopic ultrasounds for pancreatic cancer.

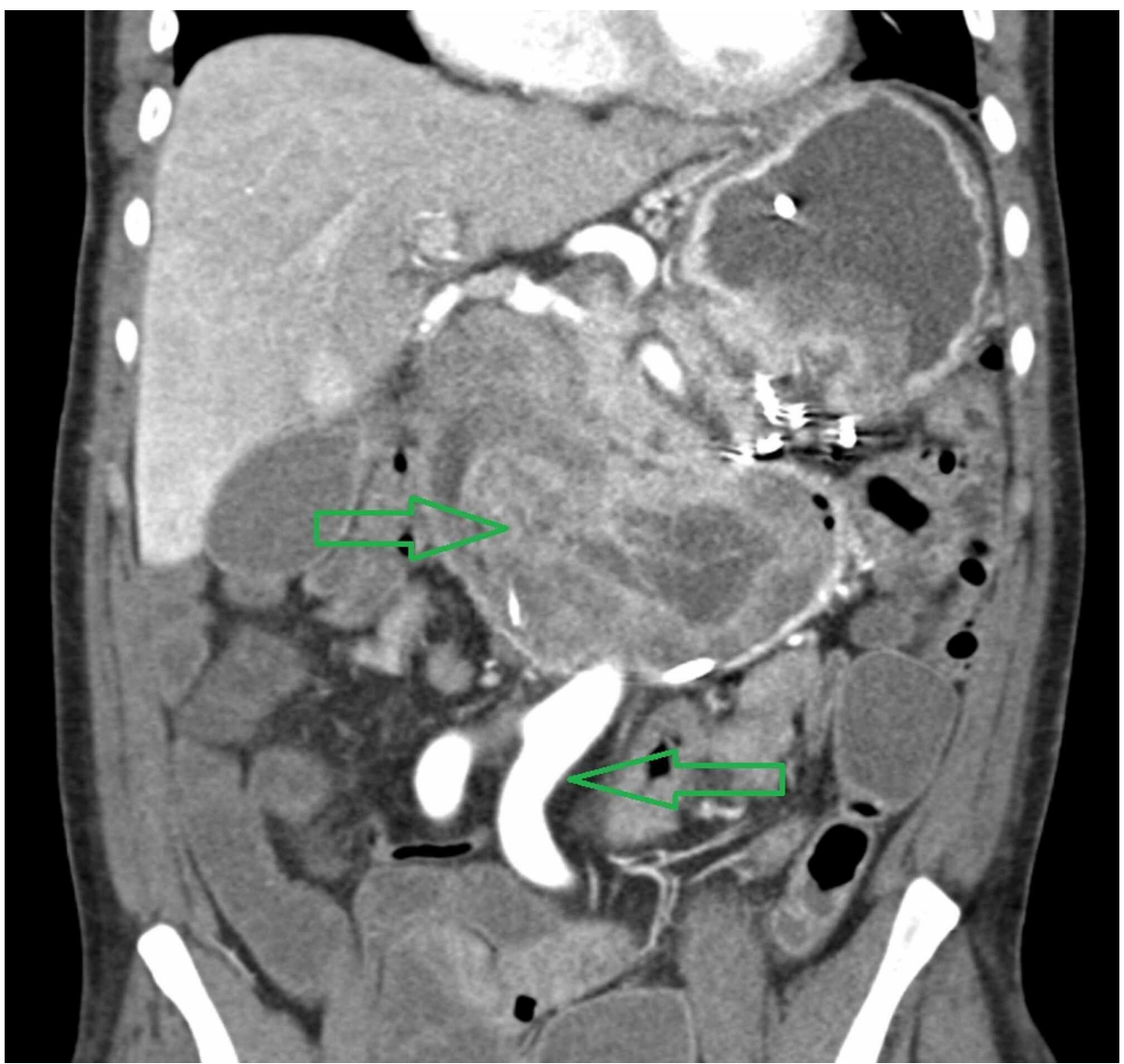

FIGURE 4: Representative image of large soft tissue density mass filling and markedly distending the duodenum and is favored to represent a pedunculated mass arising from gastric antrum that has migrated into the duodenum.

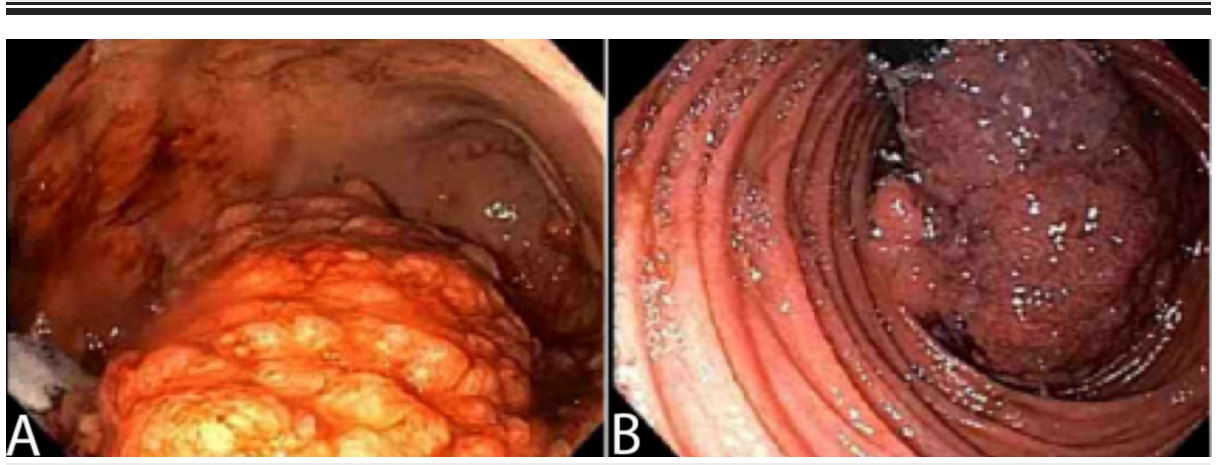

FIGURE 5: Endoscopic appearance of stomach showing large, fungating, partially circumferential mass (A) and retroflexed view from fourth portion of duodenum showing large nearly obstructive duodenal mass extending the full range of duodenum (B). 


\section{Cureus}

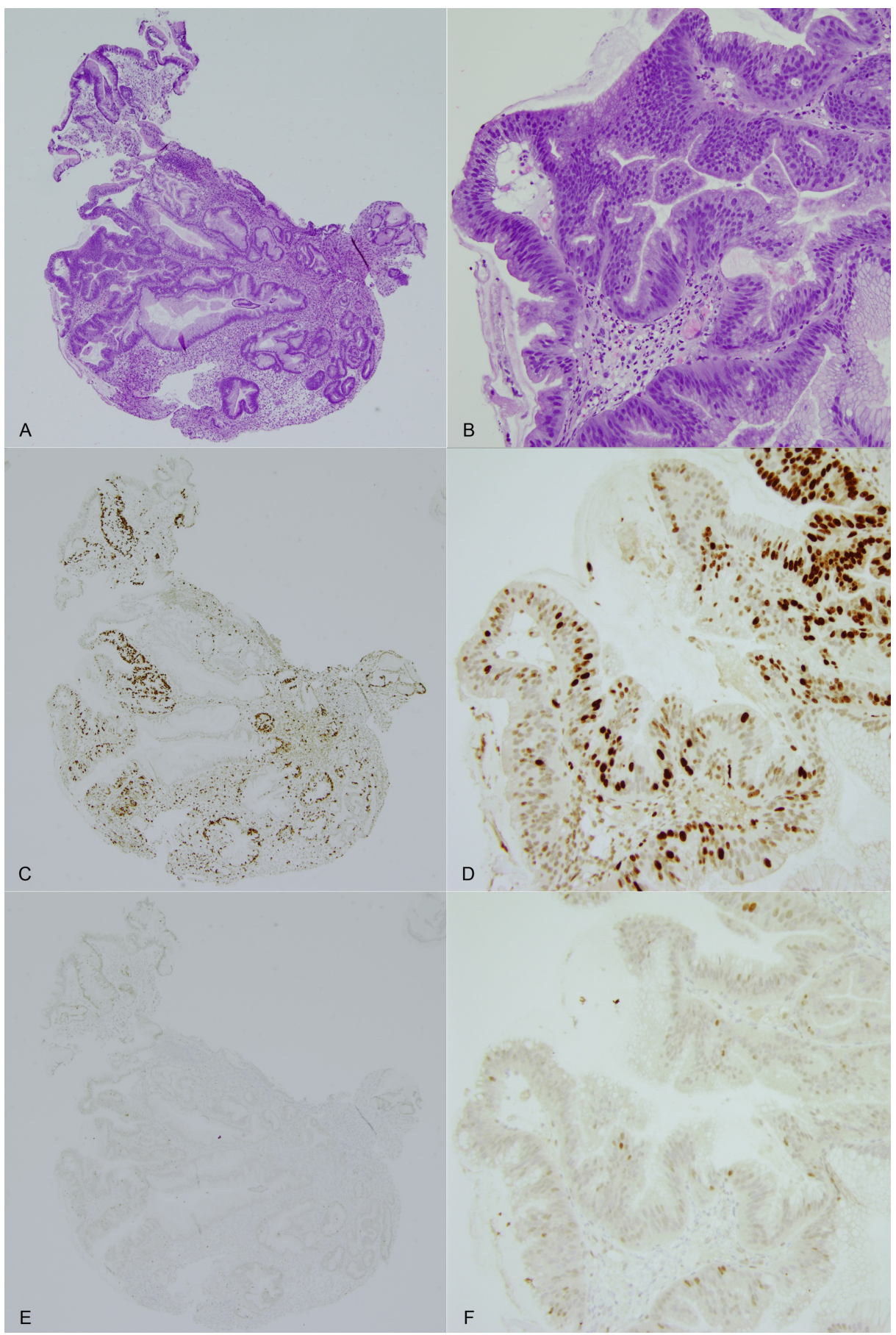

FIGURE 6: Hematoxylin and eosin-stained sections at $40 x$ and $200 x$ magnification.

Hematoxylin and eosin-stained sections at $40 x$ and $200 x$ magnification show a gastric adenoma in the left half of the specimen, with foveolar epithelium in the adjacent right half. Goblet cells are seen at lower magnification (A) in the top left corner (A-B). Immunohistochemical staining for MIB-1 (Ki-67) at 40x and 200x magnification shows increased proliferative activity in the adenoma portion, with minimal activity in the adjacent foveolar epithelium (C-D). Immunohistochemical staining for p53 at 40x and 200x, which is used to highlight high-grade dysplasia, shows rare positive cells in the adenoma portion of the specimen and no staining in the adjacent epithelium (E-F).

\section{Discussion}

This patient benefited from octreotide treatment as aberrant lab values normalized, gastric mucosa regressed, and clinical symptoms subsided after completing 12 months of octreotide treatment. This is consistent with a few other published cases of MD treated with octreotide (Table 2) [7-13]. The majority of these patients were males between the age group of 30-75 years and underwent treatment ranging from 3-15 
months. The treatment protocol utilized in these cases was either $20 \mathrm{mg}$ octreotide LAR every 28 days alone or $100-500 \mu g$ octreotide daily followed by $20 \mathrm{mg}$ of octreotide LAR at every 28 -day dosing. In our patient, there was a trend towards normalization of laboratory values and improvement in clinical symptoms within 6-12 months of octreotide treatment. Unfortunately, despite improved symptoms and signs, he developed intestinal obstruction from a gastric adenoma requiring gastrectomy. Given the timing of the adenoma appearance, one may suggest a relationship between either MD or octreotide treatment and adenoma. In addition, there is currently a hypothesis that MD is a premalignant condition. According to Hsu et al. [14], about $6-10 \%$ of patients with MD later develop gastric adenocarcinoma. While the exact etiology of this adenoma is unknown, JPS may have played a larger role than the MD or octreotide therapy.

\begin{tabular}{|c|c|c|c|c|c|}
\hline Author/Year & $\begin{array}{l}\text { Age } \\
\text { (Year)/Sex }\end{array}$ & Method of Diagnosis & Treatment & $\begin{array}{l}\text { Duration } \\
\text { of } \\
\text { Treatment }\end{array}$ & Outcome of treatment \\
\hline $\begin{array}{l}\text { Chebli et al. } \\
2017 \text { [7] }\end{array}$ & 54/Male & $\begin{array}{l}\text { Elevated alpha-1 } \\
\text { antitrypsin, endoscopy } \\
\text { and subsequent biopsy }\end{array}$ & $\begin{array}{l}\text { 20mg octreotide LAR once } \\
\text { every } 28 \text { days w/ high protein } \\
\text { diet }\end{array}$ & 3 months & Asymptomatic, increased albumin \\
\hline $\begin{array}{l}\text { Xiong and } \\
\text { Gong } 2016 \\
\text { [8] }\end{array}$ & 56/Male & $\begin{array}{l}\text { Endoscopy and } \\
\text { subsequent biopsy }\end{array}$ & $\begin{array}{l}20 \mathrm{mg} \text { octreotide LAR once } \\
\text { every } 28 \text { days }\end{array}$ & 3 months & $\begin{array}{l}\text { Treatment started after symptoms } \\
\text { and lab values stabilized, little/no } \\
\text { regression of gastric mucosa }\end{array}$ \\
\hline $\begin{array}{l}\text { Nardo et al. } \\
2012 \text { [9] }\end{array}$ & 4/Male & $\begin{array}{l}\text { Endoscopy and } \\
\text { subsequent biopsy }\end{array}$ & $\begin{array}{l}50 \mu g \text { octreotide twice a day } \\
\text { followed by Octreotide LAR } \\
5 \mathrm{mg} \text { once every } 28 \text { days }\end{array}$ & 15 months & $\begin{array}{l}\text { Asymptomatic, normalized } \\
\text { hemoglobin, slight regression of } \\
\text { gastric mucosa }\end{array}$ \\
\hline $\begin{array}{l}\text { Rothenberg } \\
\text { et al. } 2009 \\
{[10]}\end{array}$ & 75/Male & $\begin{array}{l}\text { Endoscopy and } \\
\text { subsequent biopsy }\end{array}$ & $\begin{array}{l}150 \mu \mathrm{g} \text { octreotide every } 8 \mathrm{hrs} \\
\text { followed by } 20 \mathrm{mg} \text { Octreotide } \\
\text { LAR }\end{array}$ & 3 months & $\begin{array}{l}\text { Asymptomatic, normalized } \\
\text { albumin, normal gastric mucosa }\end{array}$ \\
\hline $\begin{array}{l}\text { Gadour et } \\
\text { al. } 2005 \text { [11] }\end{array}$ & 31/Female & $\begin{array}{l}\text { Endoscopy and } \\
\text { subsequent biopsy }\end{array}$ & $200 \mathrm{mg}$ octreotide daily & 6 months & $\begin{array}{l}\text { Asymptomatic, normalized } \\
\text { albumin, normal gastric mucosa }\end{array}$ \\
\hline $\begin{array}{l}\text { Green and } \\
\text { Branch } \\
2004[12]\end{array}$ & 29/Male & $\begin{array}{l}\text { Elevated alpha-1 } \\
\text { antitrypsin, endoscopy } \\
\text { and subsequent biopsy }\end{array}$ & $\begin{array}{l}100 \mu \mathrm{g} 3 \text { times per day } \\
\text { followed by octreotide LAR } \\
\text { once every } 28 \text { days }\end{array}$ & 9 months & $\begin{array}{l}\text { Asymptomatic, normal albumin } \\
\text { and alpha- } 1 \text { antitrypsin }\end{array}$ \\
\hline $\begin{array}{l}\text { Yeaton and } \\
\text { Frierson } \\
1993[13]\end{array}$ & 47/Male & $\begin{array}{l}\text { Endoscopy, albumin } \\
\text { stool studies }\end{array}$ & $100 \mu \mathrm{g}$ octreotide & 12 months & $\begin{array}{l}\text { Asymptomatic, urgent } \\
\text { gastrectomy not necessary }\end{array}$ \\
\hline
\end{tabular}

TABLE 2: Published cases of Menetrier's disease treated with octreotide.

The exact pathophysiology of MD is still evolving with various potential triggers, but TGF- $\mathrm{a}$ and EGF-R seem to play a pivotal role. TGF-a is a signaling molecule ordinarily present in the stomach and is known to be one of many ligands of EGF-R. In vitro studies suggest that TGF-a causes proliferation of gastric epithelial cells, increase in mucin production, atrophy of oxyntic cells, and reduction in acid production. In mouse models, upregulation of TGF-a results in a phenotype similar to MD [15]. It is also plausible to suggest increased levels of TGF-a may play a role in the development of adenoma, as it increases the proliferation of gastric epithelial cells. However, current mouse models have not demonstrated a direct link between TGF- $a$ and gastric adenoma [16]. Using the elevated TGF-a hypothesis, it is difficult to directly link the development of an adenoma in our patient with his MD.

The pharmacology of octreotide, a somatostatin analog, in MD is multifactorial. On a molecular level, somatostatin has been postulated to affect TGF-a/EGF-R signaling at multiple points. First, somatostatin reduces the number of EGF-R on the cell surface, resulting in decreased TGF- $\mathrm{a} / \mathrm{EGF}-\mathrm{R}$ signaling [17]. Second, certain downstream elements (e.g., mitogen-activated protein kinase [MAPK]) are shared between EGF-R and the somatostatin receptor. By activating somatostatin receptors, octreotide may weaken EGF-R signaling, which is increased in MD via these downstream elements [18]. Third, a subtype of somatostatin receptor (SST5) may heterodimerize with EGF-R after binding with octreotide, resulting in an altered interaction between TGF- $a$ and EGF-R [19]. Given the multiple mechanisms by which octreotide inhibits the activity of EGF-R, it is unlikely that octreotide injections played a role in the pathogenesis of the adenoma.

In contrast to MD and octreotide treatment, our patient's JPS (SMAD4 mutation) was more likely to have led to the development of gastric adenoma. SMAD4 is a tumor suppressor gene involved in regulating cell growth and differentiation. Not only SMAD4 mutation implicated in JPS, but it is also linked with various 
dysplasias and malignancies, including gastric adenomas [20]. Therefore, this mutation in our patient may explain the sudden appearance of the large gastric adenoma.

\section{Conclusions}

In conclusion, $\mathrm{MD}$ is a rare disease in which the treatment guidelines are not well established. The available literature on the use of octreotide in MD is limited, and thus our case report further strengthens its position among available treatment options. We showed that octreotide could provide meaningful clinical and laboratory improvement in MD, as well as possibly delay the need for gastrectomy. Furthermore, our case also highlights a unique presentation of MD in the form of gastric outlet obstruction secondary to gastric adenoma, which may be explained by underlying JPS with SMAD4 mutation.

\section{Additional Information \\ Disclosures}

Human subjects: Consent was obtained by all participants in this study. Conflicts of interest: In compliance with the ICMJE uniform disclosure form, all authors declare the following: Payment/services info: All authors have declared that no financial support was received from any organization for the submitted work. Financial relationships: All authors have declared that they have no financial relationships at present or within the previous three years with any organizations that might have an interest in the submitted work. Other relationships: All authors have declared that there are no other relationships or activities that could appear to have influenced the submitted work.

\section{References}

1. Levitt DG, Levitt MD: Protein losing enteropathy: comprehensive review of the mechanistic association with clinical and subclinical disease states. Clin Exp Gastroenterol. Jul. 2017, 10:147-168. 10.2147/CEG.S136803

2. Nomura S, Settle SH, Leys CM: Evidence for repatterning of the gastric fundic epithelium associated With Ménétrier’s disease and TGF $\alpha$ overexpression. Gastroenterology. 2005, 128:1292-1305. 10.1053/i.gastro.2005.03.019

3. Badov D, Lambert JR, Finlay M, Balazs MD: Helicobacter pylori as a pathogenic factor in Menetrier's disease Am J Gastroenterol. 1998, 93:1976-1979. 10.1016/S0002-9270(98)00228-7

4. Bayerdorffer E, Ritter M, Hatz R, Brooks W, Ruckdeschel G, Stolte M: Healing of protein losing hypertrophic gastropathy by eradication of Helicobacter pylori--is Helicobacter pylori a pathogenic factor in Menetrier's disease?. Gut. 1994, 35:701-704. 10.1136/gut.35.5.701

5. Fiske WH, Tanksley J, Nam KT, et al.: Efficacy of cetuximab in the treatment of Menetrier's disease . Sci Transl Med. 2009, 1:8-18. 10.1126/scitranslmed.3000320

6. Robert J, Coffey J, Jarred T: Pierre Ménétrier and his disease. Trans Am Clin Climatol Assoc. 2012, 123:126134.

7. Chebli JM, Chebli LA, Ribeiro TC, Gaburri PD: Severe hypoproteinemia as a harbinger of Menetrier's disease in autoimmune pancreatitis. Rev Assoc Med Bras. 2017, 63:215-218. 10.1590/1806-9282.63.03.215

8. Xiong LS, Gong YY: Natural history of adult-onset Menetrier disease: Report of a case with 9-year follow up . Exp Ther Med. 2016, 11:2462-2466. 10.3892/etm.2016.3181

9. Giovanni DN, Salvatore O, Marina A: A pediatric non-protein losing Menetrier's disease successfully treated with octreotide long acting release. World J Gastroenterol. 2012, 18:2727-9. 10.3748/wjg.v18.i21.2727

10. Rothenberg M, Pai R, Stuart K: Successful use of octreotide to treat Menetrier's disease: A rare cause of abdominal pain, weight loss, edema and hypoalbuminemia. Dig Dis Sci. 2009, 54:1403-1407. 10.1007/s10620-009-0754-z

11. Gadour MO, Salman AH, El Samman ETW, Tadros NM: Menetrier's disease: an excellent response to octreotide. A case report from the Middle East. Trop Gastroenterol. 2005, 26:129-131.

12. Green BT, Branch MS: Menetrier's disease treated with octreotie long-acting release. Gastrointest Endosc. 2004, 60:1028-9. 10.1016/S0016-5107(04)02215-1

13. Yeaton P, Frierson HF Jr: Octreotide reduces enteral protein losses in Menetrier's disease . Am J Gastroenterol. 1993, 88:95-8.

14. Hsu CT, Ito M, Kawase Y, Sekine I, Ohmagari T, Hashimoto S: Early gastric cancer arising from localized Ménétrier's disease. Gastroenterol Jpn. 1991, 26:213-217. 10.1007/BF02811083

15. Dempsey PJ, Goldenring JR, Soroka CJ, Modlin IM: Possible role of transforming growth factor alpha in pathogenesis of Menetrier's disease: supportive evidence from human and transfenic mice. Gastroenterology. 1992, 103:1950-63. 10.1016/0016-5085(92)91455-D

16. Yu S, Yang M, Nam KT: Mouse models of gastric carcinogenesis. J Gastric Cancer. 2014, 14:67-86. 10.5230/igc. 2014.14.2.67

17. Pinski J, Halmos G, Schally AV: Somatostatin analog RC-160 and bombesin/gastrin-releasing peptide antagonist RC-3095 inhibit the growth of androgen-independent DU-145 human prostate cancer line in nude mice. Cancer Lett. 1993, 71:189-96. 10.1016/0304-3835(93)90115-P

18. Lahlou H, Guillermet J, Hortala M: Molecular signaling of somatostatin receptors. Ann N Y Acad Sci. 2004, 1014:121-31. 10.1196/annals.1294.012

19. Watt HL, Kharmate GD, Kumar U: Somatostatin receptors 1 and 5 heterodimerize with epidermal growth factor receptor: agonist-dependent modulation of the downstream MAPK signaling pathway in breast cancer cells. Cell Signal. 2009, 21:428-39. 10.1016/j.cellsig.2008.11.012

20. Kim JY, Park DY, Kim GH, Choi KU: Smad4 expression in gastric adenoma and adenocarcinoma: frequent loss of expression in diffuse type of gastric adenocarcinoma. Histol Histopathol. 2005, 20:543-9. 


\section{Cureus}

$10.14670 / \mathrm{HH}-20.543$ 